\title{
Total Recovery from Monoclonal Gammopathy and Autoimmune Phenomena After Parathyroidectomy
}

\author{
Carlos A. Cañas ${ }^{*}, 1$, Andrés F. Echeverri ${ }^{1}$ and Juan-Manuel Anaya ${ }^{2}$ \\ ${ }^{I}$ Unit of Rheumatology, Fundación Valle del Lili, Cali, Colombia \\ ${ }^{2}$ Center for Autoimmune Diseases Research (CREA), Universidad del Rosario, Bogotá, Colombia
}

\begin{abstract}
Based on the observation of a patient with a causal relationship between hyperparathyroidism and development of both autoimmune disease and paraproteinemia, we hypothesize a novel cause of autoimmunity triggered in the context of hyperparathyroidism.
\end{abstract}

Keywords: Primary hyperparathyroidism, parathyroid adenoma, Sjögren's syndrome, benign monoclonal gammopathy.

\section{INTRODUCTION}

Monoclonal gammopathies have been observed in nearly $15 \%$ of the patients with Sjogrën's syndrome (SS), a chronic autoimmune rheumatic disease characterized by salivary and lacrimal gland destruction which progresses to xerostomia and xerophthalmia related to chronic B lymphocyte activation [1,2]. There are no reports of an association between SS and primary hyperparathyroidism (PHPT) although an association between PHPT and monoclonal gammopathy has been observed [3], and its resolution is possible with the excision of the parathyroid adenoma $[4,5]$. Herein we report a patient with SS and benign monoclonal gammopathy who was diagnosed and treated for PHPT. Her autoimmune disease and paraproteinemia disappeared after resection of the parathyroid adenoma.

\section{CASE REPORT}

A 56-year-old woman was admitted due to symptomatic hypercalcemia manifested by malaise and weakness. She had previously been diagnosed for SS because of a three year history of xerostomia, xerophthalmia, dry nose, vaginal dryness, xeroderma, fatigue and arthritis in the proximal interphalangeal and metatarsophalangeal joints with the presence of positive antinuclear antibodies (ANAs), anti-Ro and anti-La antibodies, hypergammaglobulinemia as well as a biopsy of minor salivary glands disclosing focal sialodenitis a focus score of 3. Cardiopulmonary, digestive, genitourinary, or neurological symptoms were absent. She had abnormal renal function tests including increased levels of creatinine, and non-nephrotic proteinuria. A renal biopsy was done three months before admission which revealed interstitial renal disease with focal segmental glomerulosclerosis. These findings were suggestive of nephropathy associated with SS. Therefore, she was treated with $200 \mathrm{mg}$ of hydroxychloroquine per day, methylprednisolone $32 \mathrm{mg}$ per day, azathioprine $100 \mathrm{mg}$ per day and enalapril $5 \mathrm{mg}$ per day.

*Address correspondence to this author at the Fundación Valle del Lili, Unit of Rheumatology, Carrera 98 18-49, Cali, Colombia, Tel: (57)23317474;

E-mail: cacd12@hotmail.com
On admission, on physical examination, her blood pressure was 120/80 mm Hg; 70 beat per minute. Head and neck were normal. Xerophthalmia and xerostomia were present, but there was no parotid swelling or oral ulcers. Cardiopulmonary, cutaneous, neurological and osteoarticular systems were normal. General screening test was done where severe hypercalcemia and high levels of parathyroid hormone were documented (Table 1). A parathyroid scintigraphy showed a parathyroid adenoma. Serum protein electrophoresis showed a typical monoclonal band at gamma zone. The anemic state was interpreted as multifactorial: anemia of chronic disease, kidney failure and autoimmune hemolytic component. Neck surgery was performed finding a retrothyroid mass which was resected and a parathyroid adenoma was histopathologically confirmed. After two days of parathyroidectomy, the levels of calcium and parathyroid hormone turned to normal levels. Calcium and calcitriol were indicated after surgery. No hunger bone syndrome status was presented. After two months, the patient's joint pain and sicca-symptoms improved with a significant decrease in levels of calcium, parathyroid hormone, autoantibodies and gammaglobiulins. One year later, it was possible to withdraw steroid and immunosupresive drugs. Two years later, she was asymptomatic without treatment and her laboratory exams were normal including to serum protein electrophoresis (Table 1).

\section{DISCUSSION}

PHPT is associated with diverse rheumatologic manifestations, for example, osteitis, pseudogout, muscular debility and osteoporosis. The association with gammopathies has been described in medical literature as case reports. A prospective, controlled study showed a high prevalence $(10 \%)$ of this association [3]. After the removal of the parathyroid adenoma, some patients presented remission of hyperparathyroidism and gammopathy, which would suggest a causal relationship [3,4]. The most likely explanation for this phenomenon is the effect of the parathyroid hormone (PTH) on stromal cells (i.e. osteoblasts), inducing the release of interleukin-6 (IL-6), which in turn stimulates B lymphocytes for activation and 
Table 1. Laboratory Analyses and Medical Treatment Before the Parathyroidectomy and Changes Described After Surgery

\begin{tabular}{|c|c|c|c|c|c|}
\hline Hematocrit & $36.0-46.0 \%$ & 27 & 32 & 42 & $*$ \\
\hline White-cell count & $4500-11,000 / \mathrm{mm} 3$ & 3640 & 8420 & 7250 & \\
\hline Neutrophils & $36.0-46.0 \%$ & 57 & 83 & 81 & \\
\hline Monocytes & $4-11 \%$ & 10 & 4 & 5 & \\
\hline Eosinophils & $0-8 \%$ & 7 & 1 & 1 & \\
\hline Basophils & $0-3 \%$ & 2 & 1 & 0 & \\
\hline Platelet count & $150-400 \mathrm{~mm} 3$ & 256.000 & 344.000 & 340.000 & \\
\hline ERS $\mathrm{ml} / \mathrm{h}$ & $1-20 \mathrm{ml} / \mathrm{h}$ & 58 & 6 & 7 & $*$ \\
\hline Creatinine $(\mathrm{mg} / \mathrm{dl})$ & $0.6-1.1 \mathrm{mg} / \mathrm{dl}$ & 1.9 & 1.92 & 1.1 & $*$ \\
\hline ALT & 7-30 u/liter & 8.2 & 37.9 & 14.0 & \\
\hline AST & $9-32 \mathrm{u} /$ liter & 25 & 28.5 & 20.0 & \\
\hline Calcium & $8.5-10.5 \mathrm{mg} / \mathrm{dl}$ & 11.2 & 8.2 & 9.1 & $*$ \\
\hline phosphorus & $2.6-4.5 \mathrm{mg} / \mathrm{dl}$ & 4.1 & 3.84 & 3.7 & \\
\hline Sodium & $135-145 \mathrm{mmol} / \mathrm{L}$ & 140 & 135 & 139 & \\
\hline Potassium & $3.4-4.8 \mathrm{mmol} / \mathrm{L}$ & 4.4 & 4.16 & 4.1 & \\
\hline Parathyroid hormone & $10-65 \mathrm{pg} / \mathrm{ml}$ & 213 & 82.9 & 34 & $*$ \\
\hline TSH & 0.4- $4 \mu \mathrm{U} / \mathrm{ml}$ & 1.76 & 0.86 & 1.7 & \\
\hline Direct coombs & Negative & Positive ++ & Negative & Negative & $*$ \\
\hline HCV Antibodies & & Negative & & & \\
\hline HBsAg & & Negative & & & \\
\hline Proteinuria & $0 \mathrm{mgr} / \mathrm{dL}$ & 150 & 40 & 0 & \\
\hline Serum albúmine & $2.9-4.9 \mathrm{gr} / \mathrm{dl}$ & 4.2 & 3.13 & 4.3 & \\
\hline Serum $\alpha 1$ globuline & $0.08-0.36 \mathrm{gr} / \mathrm{dl}$ & 0.2 & 0.1 & 0,2 & \\
\hline Serum $\alpha 2$ globuline & $0.44-1.09 \mathrm{gr} / \mathrm{dl}$ & 0.84 & 0.65 & 0.9 & \\
\hline Serum $\beta 1$ globuline & $0.66-1.05 \mathrm{gr} / \mathrm{dl}$ & 0.66 & 0.64 & 0.9 & \\
\hline Serum $\gamma$ globuline & $0.57-1.95 \mathrm{gr} / \mathrm{dl}$ & 2.1 & 0.32 & 0.89 & $*$ \\
\hline Serum Kappa chain & 574- 1276 & 2140 & 519 & 502 & $*$ \\
\hline Serum lambda chain & $269-632$ & 952 & 263 & 308 & $*$ \\
\hline Urine Kappa chain & $<1.85 \mathrm{mg} / \mathrm{dl}$ & 2.59 & $<1.85$ & $<1.85$ & \\
\hline Urine Lambda chain & $<5 \mathrm{mg} / \mathrm{dl}$ & 5.2 & $<5$ & $<5$ & \\
\hline \multicolumn{6}{|l|}{ Medical Treatment } \\
\hline Prednisone & & $25 \mathrm{mg} / \mathrm{d}$ & $10 \mathrm{mg} / \mathrm{d}$ & Withdraw & \\
\hline Hydroxychloroquine & & $200 \mathrm{mg} / \mathrm{d}$ & $100 \mathrm{mg} / \mathrm{d}$ & Withdraw & \\
\hline Azathioprine & & $100 \mathrm{mg} / \mathrm{d}$ & $50 \mathrm{mg} / \mathrm{d}$ & Withdraw & \\
\hline
\end{tabular}

*Variable normalization. ${ }^{* *}$ Significant decline in the variable. ESR: Erytrosedimentation rate. CRP: reactive C-protein. ALT: Alanine aminotransferase. AST: Aspartate aminotransferase. HBsAg: hepatitis B virus surface antigen. $\mathrm{HCV}$ : hepatitis $\mathrm{C}$ virus. 
differentiation of plasmocytes and the subsequent production of antibodies [6,7]. Additionally, IL-6 is produced and secreted by human parathyroids and it is probable that this production and secretion contribute directly to the elevation of its serum levels in patients with PHPT [8]. Unfortunately, in the series it was not possible to measure serum IL-6 because this assay is not available in our country. A causal association between PHPT and autoimmune processes is theoretically likely based on humoral immunity activation. However, this condition has not been demonstrated.

IL-6 would be the most likely link between PHPT and stimulation of B lymphocytes and plasma cells which, in the current presentation, is associated with the development of gammopathy and SSP, and they improve with the treatment of PHPT. Some symptoms associated with PHPT such as fatigue and arthralgia might also be explained through various proinflammatory effects of IL-6. Recalling that, this cytokine is also produced by monocytes, macrophages, $\mathrm{T}$ lymphocytes, B lymphocytes, endothelial cells, etc., which stimulate other cells that trigger other biological effects [9].

In summary, we report a patient presenting with monoclonal gammopathy and interstitial renal disease associated with SS and HPTH. A striking improvement in clinical and laboratory aspects was observed after parathyroidectomy. To the best of our knowledge the association between PTHP and SS has not been reported previously. Further studies to understand the role of PTH in the autoimmune process are needed. This case presents a sequence of events that make us assume a form of autoimmune trigger.

\section{ACKNOWLEDGEMENT}

Declared None.

\section{CONFLICT OF INTEREST}

The authors confirm that this article content has no conflicts of interest.

\section{REFERENCES}

[1] Anaya JM, Talal N. Sjögren's syndrome and connective tissue diseases associated with other immunologic disorders. In: Koopman WJ, Ed. Arthritis and allied conditions. $13^{\text {th }}$ ed. Baltimore: William \& Wilkins 1997; pp.1561-80.

[2] Youinou P, Saraux A, Pers JO. B-Lymphocytes govern the Pathogenesis of Sjögren's Syndrome. Curr Pharm Biotechnol 2012. [Epub ahead of print].

[3] Khammassi N, Riahi L, Mohsen D, Tougourti MN, Hamza M. Primary hyperparathyroidism and monoclonal gammopathy of undetermined significance: a new observation and literature review. Tunis Med 2010; 88(4) : 296.

[4] Arnulf B, Bengoufa D, Sarfati E, et al. Prevalence of monoclonal gammopathy in patients with primary hyperparathyroidism: a prospective study. Arch Intern Med 2002; 25: 464-7.

[5] Cañas CA. Relación entre hiperparatiroidismo y gamapatía monoclonal. Acta Med Colomb 2007; 32: 219-22.

[6] Uyttenhove C, Coulie PG, Van Snick J. T cell growth and differentiation induced by interleukin-HP1/IL-6, the murine hybridoma/ plasmacytoma growth factor. J Exp Med 1988; 167: 1417-27.

[7] Nordan RP, Pumphrey JG, Rudikoff S. Purification and NH2terminal sequence of a plasmacytoma growth factor derived from the murine macrophage cell line P388D1. J Immunol 1987; 139: 813-7.

[8] Safley SA, Villinger F, Jackson EH, Tucker-Burden C, Cohen C, Weber CJ. Interleukine-6 production and secretion by human parathyroids. Clin Exp Immunol 2004; 136: 145-56.

[9] Youinou P, Jamin C. The weight of interleukin-6 in B cell-related autoimmune disorders. J Autoimmun 2009; 32: 206-10. 